\title{
Influence of Iodine on Efficiency of Fish
}

\author{
A. A. Vasiliev ${ }^{1}$, I. V. Poddubnaya ${ }^{1}$, I. V. Akchurina ${ }^{1}$, Ol. Ye. Vilutis ${ }^{1} \&$ P. S. $\operatorname{Tarasov}^{1}$ \\ ${ }^{1}$ FGBOU VPO, Saratov State Agrarian University named after N. I. Vavilov, Saratov, Russia \\ Correspondence: A. A. Vasiliev, FGBOU VPO, Saratov State Agrarian University named after N. I. Vavilov, \\ 410012, Teatralnaya pl. 1, Saratov, Russia. Tel: 7-927-221-8314. E-mail: alekseyvasiliev@yandex.ru
}

Received: July 13, 2014 Accepted: July 30, 2014 Online Published: September 15, 2014

doi:10.5539/jas.v6n10p79 URL: http://dx.doi.org/10.5539/jas.v6n10p79

\begin{abstract}
In accordance with the level of iodine consumption in the composition of granulated compound feedstuff given to the youngsters of the Lena sturgeon the influence of increased iodine norms on the synthesis of thyroxin, functional state of thyroid, fish fertility, feedstuff costs upon the amount of growth and economic efficiency has been marked.
\end{abstract}

Keywords: fish, feedstuffs, feeding, iodine, iodinated feeding product

\section{Introduction}

In the conditions of reduction of marine fish catches and depletion of fish stock in inland water reservoirs the reliable source of raising the volumes of food fish produce is aquaculture. In connection with the trend pickup of intensification measures in fish-farms the acceleration of the growth of fish acquired its significance. For this purpose in practice of domestic and foreign fish breeding various stimulators are already used at growing of thresh fish, including some hormonal preparations. For example, some researchers (Garg, 2007; Higgs, 1992) suggest to use the diets enriched by low doses of L-thyroxin (up to $50 \mathrm{mg} / \mathrm{kg}$ ) as a result of such feeding besides high fish growth rates, low coefficient of conversion of forage, high rates of comprehensibility of protein and enzymes activity of digestive tract are noted. According to the authors, there is no risk for consumers of the given fish in connection with high level of hormone metabolism and its removal from the organism.

Very important microcell in fish feeds is iodine, its low concentration in fresh water leads to the necessity to control its presence in the compound feedstuffs. The value of iodine is defined by the fact that it is an obligatory structural component of hormones (Akchurina, 2013; Vilutis, 2014) of thyroid, and in case of its insufficient receipt in an organism from environment intensity of biosynthesis of hormones decreases.

The research is actively conducted in the world during the last decades on application of iodine bearing supplements in feeding the sturgeon in industrial fish breeding aiming at raising fish productivity, resistance to diseases and unfavorable conditions of the environment.

To study the iodine influence on the productivity of fish compound feedstuff supplement Abiopeptid was chosen as the base. Abiopeptid is $25 \%$ concentrate of fermentative hydrolyzed vegetable protein of soya. Organic iodine has been dissolved in this supplement in various concentrations to find the optimal doze of its efficiency. Feed supplement Abiopeptid with different iodine concentrations for the experiment was produced and presented by the scientific research-production company limited liability $A-B I O$, the town of Puschino situated in the Moscow area. Iodine in the supplement was present in the most available to be digested and harmless organic form of iodinegorgone acid, where iodine is bound in the stable complex with amino acid.

It is known that feed supplement Abiopeptid increases the content of general protein and its gamma globulin fractions in animals and birds, bactericide activity, lysozyme activity in blood serum, hemoglobin concentration and other hematologic indicators, which testifies the intensification of exchange processes and the raising of organism's resistance. There have been lately obtained the data on the efficiency of protein hydrolyzates in the compounds with organic iodine under application of various livestock feedstuffs. Nevertheless, the efficiency of feedstuff supplement Abiopeptid with the iodine compound in feeding fish has not been studied up to nowadays yet.

In our research we studied the joint Abiopeptid and iodine effect upon the Lena sturgeon. Such biological peculiarities of the Lena sturgeon as high plasticity, resistance to high temperatures, the ability to use granulated 
feedstuffs make it to be a prospective object of industrial and pond fish breeding industry. The most successful practice of its breeding is in warm waters, because the Lena sturgeon is eurythermal, it can bear the water temperatures raise up to $30{ }^{\circ} \mathrm{C}$. The sturgeon grows most intensively under the temperature of $15-20{ }^{\circ} \mathrm{C}$. Its growth continues under low temperatures $\left(10-11^{\circ} \mathrm{C}\right)$ as well (Ponomaryev, 2011).

\section{Material and Methods}

Experiment on the influence of iodine bearing supplement was conducted in the aquarium installation (Vasiliev, 2010 ) in the scientific research laboratory The technologies of fish growing and feeding FGBOU VPO Saratov State N.Vavilov Agrarian University, on the account of the RF presidential grant's fund aimed to give state support to young Russian scientists No. MD-6254.2014.4.

The Lena sturgeon youngsters were divided according to the analogues' principle into 5 groups: 4 - experimental and 1 controlling. In each group there were 11 individuals. The medium weight of the fish at the start of the experiment was $280 \pm 2.9$ grams. Experiment was being performed during 45 days. The fish from the experimental and controlling groups was given compound feedstuffs (BD) containing $47 \%$ rough protein, $13 \%$ rough fat, $2.8 \%$ cellulose and enriched by vitamins A, D3, C, E. Experimental groups got BD with the feedstuff supplement Abiopeptid, iodinated by various quantity of organic iodine. The dosage of the feed supplement Abiopeptid in all the groups constituted $1 \mathrm{ml}$ per $1 \mathrm{~kg}$ of the fish mass. The iodine dosage in the groups is given in Table 1.

The sturgeons were fed two times a day, at 7:00 a.m. and at 19:00 p.m. The daily norm was counted according to the common methodic taking into the account water temperature, the content in water of dissolved oxygen and fish mass. To correct daily norm of feeding the control of the fish growth was conducted every seven days. Water temperatures, $\mathrm{pH}$, the content of dissolved oxygen were detected daily at 12:00 a.m.

Table 1 . The scheme of the trial

\begin{tabular}{|c|c|c|c|}
\hline \multicolumn{2}{|l|}{ Group } & The number of individuals & Feeding type \\
\hline \multicolumn{2}{|l|}{ Controlling } & 11 & $\begin{array}{l}\text { Granulated feedstuff with feed Abiopeptid, calculated } \\
\text { as } 1 \mathrm{ml} \text { of additive per } 1 \text { fish mass kgp (BD) }\end{array}$ \\
\hline \multirow{4}{*}{ Experimental } & 1 & 11 & $\begin{array}{l}\text { BD with iodine additive calculated as } 100 \mathrm{mkg} \\
\text { per } 1 \text { fish mass } \mathrm{kg}\end{array}$ \\
\hline & 2 & 11 & $\begin{array}{l}\text { BD with iodine additive calculated as } 150 \mathrm{mkg} \\
\text { per } 1 \text { fish mass } \mathrm{kg}\end{array}$ \\
\hline & 3 & 11 & $\begin{array}{l}\text { BD with iodine additive calculated as } 200 \mathrm{mkg} \\
\text { per } 1 \text { fish mass } \mathrm{kg}\end{array}$ \\
\hline & 4 & 11 & $\begin{array}{l}\text { BD with iodine additive calculated as } 500 \mathrm{mkg} \\
\text { per } 1 \text { fish mass } \mathrm{kg}\end{array}$ \\
\hline
\end{tabular}

At the start and by the end of the experiment the level of thyroid hormones was being determined in the fish blood by the biochemical and immune ferment analyzer of the automatic type ChemWell.

\section{Results}

The results of our research testify that the iodinated feedstuffs additive application Abiopeptid reliably increases the productivity of the Lena sturgeon just from the first week of feeding. In the experimental groups more authenticable ichtyomass increase is being seen in comparison to the controlling group. The most increase 154.5 grams during experiment's eight weeks has been achieved in the third group where the iodine content in the ration was $200 \mathrm{mgs}$ calculated per $1 \mathrm{~kg}$ of fish mass, which is $11.1 \%$ more in comparison to the controlling group, where the gain in growth has made up 137.5 grams (Table 2). 
Table 2. The Lena sturgeon youngsters' body mass growth dynamics, grams

\begin{tabular}{cccc}
\hline Trial periods (weeks) & \multicolumn{3}{c}{ Group } \\
\cline { 2 - 4 } & Controlling & 1 Experimental & 3 Experimental \\
\hline The start of the trial & $280.8 \pm 1.9$ & $277.8 \pm 2.38$ & $285.5 \pm 2.7$ \\
2 & $310.9 \pm 3.1$ & $302.4 \pm 1.1^{*}$ & $320.4 \pm 0.9^{*}$ \\
3 & $321.3 \pm 7.1$ & $313.8 \pm 2.2^{*}$ & $332.8 \pm 0.7^{*}$ \\
4 & $332.9 \pm 4.4$ & $344.6 \pm 5.2^{*}$ & $334.8 \pm 0.8^{*}$ \\
5 & $356.5 \pm 11.6$ & $366.7 \pm 2.4^{*}$ & $354.9 \pm 3.0^{*}$ \\
6 & $367.2 \pm 9.2$ & $387.2 \pm 5.3^{*}$ & $358.9 \pm 2.1^{*}$ \\
7 & $380.1 \pm 14.2$ & $409.3 \pm 4.5^{*}$ & $375.8 \pm 2.4^{*}$ \\
8 & $418.5 \pm 5.7$ & $422.5 \pm 1.1^{*}$ & $440.0 \pm 0.4^{*}$ \\
\hline Gain, grams & 137.5 & 144.7 & 154.5 \\
\hline
\end{tabular}

Note: * - P $>0,999$.

In the first, second and fourth experimental groups there have also been higher fish mass grain rates observed compared with the controlling group accordingly $5.0 \%, 1.8 \%$ and $8.0 \%$. The application of iodine additives - 200 mkg per $1 \mathrm{~kg}$ of fish mass in feeding the Lena sturgeon makes it possible to authentically increase the gain of ichtyomass up to $11.1 \%$, opposite to the use of old standard fish feeding schemes.

The results of daily control on feedstuffs palatability presented in Table 3 show that feeding coefficient was in all the groups on the optimal level. This was due to the water temperature which during the period of the studies was in the physiological norm's optimum limits. The least feedstuff costs per $1 \mathrm{~kg}$ of fish mass gain were observed in the third and fourth experimental groups and made up 1141.7 grams of compound feedstuff. The highest indicator was in the second experimental group, it made up 1272.7 of feedstuff per $1 \mathrm{~kg}$ of gain.

Table 3. The feedstuffs given during the period of trial, grams

\begin{tabular}{cccc}
\hline & \multicolumn{3}{c}{ Group } \\
\cline { 2 - 4 } Growth period (weeks) & Controlling & \multicolumn{2}{c}{ Experimental } \\
\cline { 2 - 4 } & & 192.5 & 197.4 \\
\hline 1 & 194.6 & 215.6 & 221.9 \\
3 & 199.5 & 215.6 & 230.3 \\
4 & 203.0 & 240.1 & 231.7 \\
5 & 211.4 & 254.1 & 245.7 \\
6 & 224.0 & 269.5 & 248.5 \\
7 & 235.2 & 283.5 & 260.4 \\
8 & 243.6 & 292.6 & 304.5 \\
\hline During all the period & 270.2 & 1963.5 & 1940.4 \\
\hline Costs per 1 kg of gain & 1171.5 & 1233.6 & 1141.7 \\
\hline
\end{tabular}

The least quantity of compound feedstuff supplement Abiopeptid with iodine was taken in the feeding of the fourth experimental group 4 and constituted $208.4 \mathrm{ml}$ during the whole period. In the third experimental group there were applied $215.69 \mathrm{ml}$; in the first and second experimental groups the quantity of Abiopeptid used in feeding up authentically did not differ and made up 218.36 and $218.18 \mathrm{ml}$. Despite the fact that there was the least feed supplement used in the fourth experimental group, in experimental group 3 the insignificantly more quantity of feed supplement used in feeding promoted the raise of productivity and feeds' costs decrease per 1 
unit of gains.

General thyroxin concentration in the blood serum of the Lena sturgeon youngsters before the start of the experiment was $16.36 \pm 0.09$, free thyroxin $7.56 \pm 0.68 \mathrm{~N}$ moll per liter. The hormones indicators at the end of the experiment are given in Table 4.

Table 4. The Lena sturgeon youngsters' thyroid hormones concentration indicators at the end of the experiment

\begin{tabular}{cccc}
\hline \multirow{2}{*}{ Group } & & \multicolumn{2}{c}{ Hormones concentration } \\
\cline { 3 - 4 } & & T4 general Nmoll / & T4 free. Nmoll/1 \\
\hline Controlling & $16.46 \pm 0.08$ & $7.66 \pm 0.88$ \\
\hline \multirow{2}{*}{ Experimental } & 2 & $17.93 \pm 0.29$ & $10.06 \pm 0.14$ \\
& 3 & $22.13 \pm 0.58$ & $11.93 \pm 1.73$ \\
& 4 & $23.06 \pm 1.61$ & $16.63 \pm 0.78$ \\
& & $24.13 \pm 5.63$ & $11.23 \pm 1.58$ \\
\hline
\end{tabular}

From Table 4 we can see that the level of general thyroxin in the fish blood serum increases with the raise of iodine dosage, while the level of free thyroxin increases if iodine is added in the doses of 100,150 и $200 \mathrm{mkg} /$ $\mathrm{kg}$.

Calculation of economic efficiency of the use of the feed supplement Abiopeptid with iodine in feeding of the Lena sturgeon presented in Table 5 shows that in experimental groups the gross gain of fish exceeded the gain of fish from controlling group. In the third experimental group it reached the highest values and made $1.7 \mathrm{~kg}$. This fact testifies to positive influence of the feed additive Abiopeptid with iodine on productivity of the Lena sturgeon.

The cost of feedstuff given to fish in comparison to the feedstuff in controlling group was lower than in experimental groups. Taking into the account the equal selling price of fish (600.0 rubles) the highest profit was gained by the realization of the third experimental fish group.

The data acquired allow to make the conclusion on the expediency of feed supplement Abiopeptid application in feeding the Lena sturgeon, containing $200.0 \mathrm{mkg}$ iodine in $1.0 \mathrm{ml}$.

Table 5. Economic efficiency of use of fodder additive Abiopeptid with iodine

\begin{tabular}{lccc}
\hline \multicolumn{1}{c}{ Indicators } & \multicolumn{2}{c}{ Group } \\
\cline { 2 - 4 } & Controlling & Experimental \\
\cline { 2 - 4 } & & 60.00 & 60.00 \\
\hline The cost of 1 kg of compound feedstuffs, rubles & 60.00 & 1 & 1.94 \\
Feedstuffs given to 1 group, kg & 1.78 & 1.96 \\
The cost of given feedstuffs, rubles & 106.80 & 117.60 & 212.80 \\
The cost of 1 liter of preparation, rubles & 212.50 & 212.60 & 215.69 \\
The preparation fed, ml & 198.07 & 218.36 & 45.75 \\
The price of preparation given, rubles & 42.07 & 46.35 & 162.15 \\
The cost of compound feedstuff with preparation given to fish, rubles & 148.87 & 163.95 \\
1 kg fish realization price, rubles & 600.00 & 600.00 & 600.00 \\
Gross ichtyomass gain, kg & 1.51 & 1.59 & 1.70 \\
Profit from fish gain realization, rubles & 907.5 & 955.02 & 1019.7 \\
Profit from realization, rubles & 758.63 & 791.07 & 857.55 \\
Additionally gained profit, rubles & - & 32.44 & 98.92 \\
\hline
\end{tabular}




\section{Conclusion}

To summarize, the optimal efficiency concentration of iodine in the form of iodinegorgone acid in the feed supplement Abiopeptid composition under its application in the feeding up of the Lena sturgeon has been determined by the authors of the article.

\section{References}

Akchurina, I. V., Poddubnaya, I. V., Vasiliev, A. A., Vilutis, O. Ye., \& Tarasov, P. S. (2013). Alternative to hormonal preparates to strengthen the fish growth intensity. The Bulletin of Saratov Agrarian University in honor of N. I. Vavilov, 10, 3-4.

Garg, S. K. (2007). Effect of oral administration ofl-thyroxine $\left(\mathrm{T}_{4}\right)$ on growth performance, digestibility, and nutrient retention in Channa punctatus (Bloch) and Heteropneus tesfossilis (Bloch). Fish Psychology and Biochemistry, 33(4), 347-358. http://dx.doi.org/10.1007/s10695-007-9166-1

Higgs, D. A., Dosanjh, B. S., Uin, L. M., Himick., B. A., \& Eales, J. G. (1992). Effect of dietary lipid and carbohydrate levels and chronic 3,5,3'-triiodo-l-thyronine treatment on growth, appetite, food and protein utilization and body composition of immature rainbow trout Oncorhynchus mykiss at low temperature. Aquaculture, 105, 175-190. http://dx.doi.org/10.1016/0044-8486(92)90129-9

Ponomaryev, S. V., \& Magomayev, F. M. (2011). Sturgeon breeding put on intensive foundation. Makhachkala Eco-Express (p. 352).

Vasiliev, A. A., Volkov, A. A., Guseva, Yu. A., Korobov, A. P., \& Khandozshko, G. A. (2010). Laboratory installation for scientific research on feeding up and growing fish. Paten on useful model No. 95972 Russian Federation MPK A 01 K 63/00 C 1. Patent holder: Federal Budgetary Higher Educational Establishment Saratov State N. Vavilov Agrarian University application No.2010109565/22; announc. 15.03.2010; published 20.07.2010, Bulletin No. 20.

Vilutis, O. Ye., Poddubnaya, I. V., Vasiliev, A. A., \& Tarasov, P. S. (2014). The efficiency of feedstuffs usage by the Lena sturgeon under various levels of iodine (pp. 163-166). Collection of articles of the 8th All-Russian scientific - practical conference. Saratov.

\section{Copyrights}

Copyright for this article is retained by the author(s), with first publication rights granted to the journal.

This is an open-access article distributed under the terms and conditions of the Creative Commons Attribution license (http://creativecommons.org/licenses/by/3.0/). 